\title{
Study on the Pharmacological Character of an Insulin-Mimetic Small Molecular Compound of Vanadyl Trehalose
}

\author{
Muhammad UMAR ${ }^{1,2}$, Wei QIAN ${ }^{1,2}$, Qiqi LIU ${ }^{1,2}$, Shuguang XING ${ }^{1,2}$, Xiaodan LI $^{1,2}$, Xingkai \\ YANG $^{1,2}$, Yu FAN ${ }^{1,2}$, Daocheng MA ${ }^{1,2}$, Pingzhe JIANG ${ }^{1,2}$, Minggang LI $^{1,2}$ \\ ${ }^{1}$ Key Laboratory for Bioactive Materials of the Ministry of Education, Institute of Molecular \\ Biology, Life Science College, Nankai University, Tianjin, China, ${ }^{2}$ State Key Laboratory of \\ Medicinal Chemical Biology, Nankai University, Tianjin, China
}

Received November 14, 2019

Accepted March 30, 2020

Epub Ahead of Print May 29, 2020

\section{Summary}

To investigate the effect of vanadyl trehalose (VT) on oxidative stress and reduced glutathione/glutathione-Stransferase (GSH/GSTs) pathway gene expression in mouse gastrointestinal tract, as well as the protective effects of vitamin C (VC) and reduced glutathione (GSH). Thirty male Kunming mice were randomly divided into five groups: control group (group A), VT group (group B), VC + VT group (group C), $\mathrm{GSH}+\mathrm{VT}$ group (group D) and VC + GSH + VT group (group E). The content of reduced glutathione (GSH) and glutathione peroxidase (GSH-Px) activity and the expressions of glutamatecysteine ligase catalytic subunit (GCLC), glutathione synthetase (GSS), regulated through glutathione reductase (GSR) and glutathione-S-transferase pi (GSTpi) in stomach and duodenum in vanadyl trehalose treated group were lower than those in group $A(P<0.05)$. The $C, D, E$ group can significantly improve the above indicators, but those only in the stomach in $E$ group reached the level of the control group. Vanadyl trehalose (VT) was able to cause oxidative stress damage to the gastrointestinal tract of mice, which affects GSH content and GSH-Px activity and interferes with the normal expression of GSH/GSTs pathway. Exogenous vitamin $\mathrm{C}$, reduced glutathione and the combination of the two could play a specific role in antioxidant protection and reduce the toxicity of vanadyl trehalose.

\section{Key words}

Vanadyl trehalose • Oxidative Stress • GSH/GSTs • Vitamin C • Glutathione

\section{Corresponding author}

M. Li, Life Science College, Nankai University, No. 94, Weijin Road, 300071, Tianjin, China. E-mail: mgl@nankai.edu.cn

\section{Introduction}

In recent years, with the improvement of people's living standards, the incidence of diabetes is increasing every year (Canivell and Gomis 2012, Radosinska et al. 2015). Diabetes mellitus is a chronic metabolic disease caused by insufficient insulin secretion or decreased insulin sensitivity in the body (Gavin et al. 1997, Whiting et al. 2013, Xiaodan et al. 2019). Vanadium can regulate the metabolism of sugar to a certain extent and anti-diabetes function (Srivastava and Mehdi, 2005, Jiang et al. 2016, Wilk et al. 2017). However, vanadium compounds, while resisting diabetes, often lead to some toxic effects (Jiang et al. 2017), mainly the digestive tract, such as diarrhea, dehydration, weight loss, etc. (Imura et al. 2013). It is reported that the mechanism of the toxicity of vanadium may be related to the free radical accumulation, the decrease of antioxidant enzyme activity such as glutathione peroxidase (GSH-Px), superoxide dismutase (SOD) and catalase (CAT) etc. and the enhancement of oxidative damage. (Liu et al. 2012, Lee et al. 2012).

Glutathione (GSH) is an important antioxidant in vivo, and its content is mainly regulated through glutathione reductase (GSR), glutathione synthetase (GSS), glutamic acid cysteine junction enzyme ( $\gamma$-GCL) 
and some glutathione-S-transferase enzyme (GSTs) (Lu 2013). These enzymes together constitute a GSH/GSTs pathway (Kalinina et al. 2014). Vitamin C is a reducing agent for chemical reactions inside and outside the cell, and a water-soluble low molecular antioxidant (Monacelli et al. 2017).

Although toxic effects have been mainly reported from inorganic forms, organic vanadium compounds have been associated with therapeutic effects. It may be due to the increased lipophilicity and gastrointestinal absorption (Wang et al. 2001). Thus, organic vanadium compounds have become a highlight. Vanadyl trehalose (VT) was originally a new type of organic vanadium compound synthesized by Barrio et al. (2003). We used a similar method to synthesize VT, found that it could regulate the blood glucose level of diabetic mice and alleviate the symptoms of diabetes such as polydipsia, polyphagia, polyuria and body mass loss (Jiang et al. 2016, Jiang et al. 2018). Further studies have found that the main toxic target organ of trehalose in Kunming mice is the stomach and duodenum (Jiang et al. 2017, Jiang et al. 2018).

This study was performed to observe the effects of vanadyl trehalose (VT) on oxidative stress and (GSH/GSTs) pathways gene expression in the stomach and duodenum of experimental mice and to explore the detoxification effect of exogenously added vitamin $\mathrm{C}$ (VC) and reduced glutathione (GSH).

\section{Methods}

\section{Laboratory animals}

Thirty male Kunming mice of SPF grade, five weeks old, were purchased from the Center of Chinese Academy of Military Medical Sciences (animal license number SCXK-2007-005). The animal room maintained temperature $20 \pm 2{ }^{\circ} \mathrm{C}$, humidity $50 \pm 5 \%$, and the light and dark cycle was $12 \mathrm{~h}: 12 \mathrm{~h}$, without strong acousto-optic stimulation. All animals were kept in the environment for 1 week, during which they were given free access to standard feed and open access to tap water.

\section{Reagents}

The main reagent vanadium sulphate was purchased from Tianjin Alfa Aesar Chemical Co., Ltd.; trehalose was purchased from Tianjin SMS Co., Ltd.; anhydrous ethanol was purchased from Tianjin Chemical Reagent Supply and Marketing Company; GSH was purchased from Beijing Solabao Company; VC was purchased from US Sigma; GSH and GSH-Px activity assay kits were purchased from Nanjing Institute of Bioengineering; RNAiso Plus was purchased from TaKaRa; FastKing cDNA first strand synthesis kit and superReal PreMix plus SYBR Green purchased from Beijing Tiangen Biochemical Technology Co., Ltd; all the primers were synthesized by Beijing Aoke Dingsheng Biotechnology Co., Ltd.

\section{Synthesis of trehalose vanadate}

The synthesis of trehalose vanadate is in accordance with the method of Barrio et al. 2003. To $10 \mathrm{ml}$ of trehalose solution $(0.4 \mathrm{~mol} / \mathrm{l})$, vanadium sulphate solution $(0.1 \mathrm{~mol} / \mathrm{l})$ was added dropwise, and then the $\mathrm{pH}$ of the mixed solution was adjusted using $\mathrm{NaOH}$ solution $(2 \mathrm{~mol} / \mathrm{l})$. The brown mixed solution was sealed at room temperature for 12 to $24 \mathrm{~h}$, anhydrous ethanol was added, and a solid was gradually precipitated, later the solid was collected by filtration and washed with water-free ethanol. The product was dried over $\mathrm{NaOH}$ solids and stored in a desiccator. Various studies have carried out using standard concentration of $\mathrm{VC}$ and GSH. The concentrations of vitamin C and GSH was measured according to $\mathrm{Su}$ et al. 2014, Zhao et al. 2018 studies. VT, VC and GSH were dissolved in distilled water and used on the same day.

\section{Experimental grouping and drug administration}

Thirty male Kunming mice were randomly divided into 5 groups and treated as follows: Group A: gavage of equal volume of normal saline; Group B: gavage of $125 \mathrm{mg} / \mathrm{kg} / \mathrm{d}$ ) VT; Group C: After gavage of $150 \mathrm{mg} / \mathrm{kg} / \mathrm{d}$ ) VC $1 \mathrm{~h}$, then gavage of $125 \mathrm{mg} / / \mathrm{kg} / \mathrm{d}$ ) VT; Group D: After gavage of $150 \mathrm{mg} / \mathrm{kg} / \mathrm{d}) \mathrm{GSH}$ for $1 \mathrm{~h}$, then gavage of $125 \mathrm{mg} / \mathrm{kg} / \mathrm{d}$ ) VT; Group E: After gavage of $150 \mathrm{mg} / \mathrm{kg} / \mathrm{d}) \mathrm{VC}+150 \mathrm{mg} / \mathrm{kg} / \mathrm{d}) \mathrm{GSH} 1 \mathrm{~h}$, then gavage of $125 \mathrm{mg} / \mathrm{kg} / \mathrm{d}$ ) VT. Each group was administered continuously for 15 days.

\section{Sampling and sample preparation after the last administration}

After the last administration, the mice in each group fasted for $24 \mathrm{~h}$. The mice were sacrificed by cervical dislocation and quickly dissected. The stomach and duodenum were rinsed 2 to 3 times in pre-cooled physiological saline, dry with filter paper. Each sample was prepared in duplicate, one part was placed in an EP tube, and stored in a refrigerator at $-20^{\circ} \mathrm{C}$ for storage; the other part was placed in a cryotube and 
frozen in liquid nitrogen, and stored in a refrigerator at $-80{ }^{\circ} \mathrm{C}$ for use. Preparation of tissue homogenate: weigh the stomach and duodenum tissue (0.2-1 g) stored at $-20{ }^{\circ} \mathrm{C}$ and add 9 times pre-cooled homogenate medium (normal saline) at $1: 9(\mathrm{~g} / \mathrm{ml})$. In the mortar, the homogenate was prepared under ice bath conditions, centrifuged at $3000 \mathrm{rpm}$ for $10 \mathrm{~min}$, and the supernatant was frozen in a refrigerator at $4{ }^{\circ} \mathrm{C}$ or frozen in a freezer at $-20{ }^{\circ} \mathrm{C}$ for use.

\section{GSH content and GSH-Px activity determination}

Reduced glutathione (GSH) content was determined by using 5,5'-dithiobis-2-nitrobenzoic acid (DTNB) method. GSH reacts with DTNB yield a colored product 5-thio-2-nitrobenzoic acid (TNB). The rate of formation of TNB, measured at $405 \mathrm{~nm}$, is proportional to the concentrations of GSH in the sample. It's a reliable method to measure reduced cysteines and other free sulfhydryls in solution. (Rahman et al. 2006). GSH-Px activity was measured by GSH oxidation. The determination and calculation of each of the above indicators were carried out in strict accordance with the procedure of the kit instructions.

\section{Real-time fluorescence quantitative PCR detection}

The total RNA of the stomach and duodenum tissues was extracted with reference to the procedure of the RNAiso Plus instruction. Total RNA concentration and purity were measured by a micro-ultraviolet analyzer (Nano Drop 2000), and RNA integrity was analyzed by agarose gel electrophoresis. The RNA extract was stored at $-80^{\circ} \mathrm{C}$ until use. The total RNA of each sample was reverse-transcribed into cDNA using the Fast King cDNA first-strand synthesis kit, and used as a template according to Super Real Pre Mix Plus SYBR Green instruction, and the relevant reagents and primers were added to carry out PCR amplification in a final reaction volume of $20 \mu \mathrm{l}$. The primer sequences used are shown in Table 1. Reaction conditions: pre-denaturation at $95^{\circ} \mathrm{C}$ for $15 \mathrm{~min}$; denaturation at $95^{\circ} \mathrm{C}$ for $10 \mathrm{~s}$, annealing at $57^{\circ} \mathrm{C}$ for $20 \mathrm{~s}$, extension at $72{ }^{\circ} \mathrm{C}$ for $20 \mathrm{~s}, 40$ cycles; detection signal at $72{ }^{\circ} \mathrm{C}$. The $\mathrm{Ct}$ value was calculated by using CFX96 PCR thermal cycler analysis software according to the formula $2^{-\Delta \Delta \mathrm{Ct}}$ and used for statistical analysis.

\section{Statistical analysis}

Statistical analysis was performed using SPSS 22.0 software. Data were expressed as mean \pm standard deviation $\left(\bar{x}_{ \pm s}\right)$. Data between groups were compared by one-way analysis of variance (ANOVA) and LSD, the difference with $\mathrm{P}<0.05$ was reputed as statistically significant. $\mathrm{F}$ is one of the most common statistical tools for hypothesis testing for the analysis of variance (ANOVA). A statistical $F$ Test use to compare two variances, $\mathrm{S}_{1}$ and $\mathrm{S}_{2}$, by dividing them. Variances are a measure of dispersion, or how far the data are scattered from the mean. The result is always a positive number (because variances are always positive). The equation for comparing two variances with the $\mathrm{F}$ Test is: $\mathrm{F}=\mathrm{S}^{2}{ }_{1} / \mathrm{S}^{2}{ }_{2}$. If $\mathrm{F}>\mathrm{F}_{0.05}$ of $\mathrm{F}_{0.01}$, indicating that the differences are significant.

Table 1. Primers sequence for real-time PC.

\begin{tabular}{lc}
\hline Gene & Sequence \\
\hline \multirow{2}{*}{ GCLC } & F: 5'-CTACCACGCAGTCAAGGACC-3' \\
& R: 5'-CCTCCATTCAGTAACAACTGGAC-3' \\
GSS & F: 5'-AAAGCAGGCCATAGACAGGG-3' \\
& R: 5'-TGAATGGGGCATACGTCACC-3' \\
GSR & F: 5'-GCGTGAATGTTGGATGTGTACC-3' \\
& R: 5'-GTTGCATAGCCGTGGATAATTTC-3' \\
GSTPI & F: 5'-ATGCCACCATACACCATTGTC-3' \\
& R: 5'-GGGAGCTGCCCATACAGAC-3' \\
GAPDH & F: 5'-TGACCTCAACTACATGGTCTACA3' \\
& R: 5'-CTTCCCATTCTCGGCCTTG-3'
\end{tabular}

\section{Results}

Comparison of GSH content in stomach and duodenum from different groups of mice

After 15 days of intervention in the 5 groups of mice, the GSH content in the stomach tissue ranged from 27.4 to $34.46 \mu \mathrm{mol} / \mathrm{g}$ protein and in the duodenum ranged from 7.4 to $56.46 \mu \mathrm{mol} / \mathrm{g}$ protein (Table 2). The GSH content was comparatively higher in duodenum than that in stomach. Statistically, the GSH values in stomach was significant $(\mathrm{F}=28.25, \mathrm{P}<0.01)$, The content of $\mathrm{GSH}$ in the stomach of VT treated mice was significantly lower than in the control group $(\mathrm{P}<0.01)$, The content of GSH in the VT-treated mice was also lower than mice in $\mathrm{VC}+\mathrm{VT}$ Group (group C), GSH + VT Group (group D) and VC + $\mathrm{GSH}+\mathrm{VT}$ Group (group E) (both $\mathrm{P}<0.01$ ); Mice having treatment of vitamin $\mathrm{C}$, GSH and vanadyl trehalose in E group have higher contents of GSH then mice of $\mathrm{C}$ and $\mathrm{D}$ group $(\mathrm{P}=0.008, \mathrm{P}=0.023)$. The difference of $\mathrm{GSH}$ contents in the stomach of mice treated with vitamin $\mathrm{C}$ 
and vanadyl trehalose of $\mathrm{C}$ group and mice treated with GSH and vanadyl trehalose of D group was statistically not significant $(\mathrm{P}=0.538)$. GSH contents of mice in control group have no significant difference than mice of E group treated with vitamin $\mathrm{C}, \mathrm{GSH}$ and vanadyl trehalose (group A) $(\mathrm{P}=0.405$, Table 2). There was a significant difference in GSH content between the duodenum of the 5 groups $(\mathrm{F}=76.17, \mathrm{P}<0.01)$. Mice treated with vanadyl trehalose has significantly lower GSH contents in duodenum then mice of control group $(\mathrm{P}<0.01)$, and the $\mathrm{C}, \mathrm{D}, \mathrm{E}$ groups were significantly higher than the mice having VT treatment in group $\mathrm{B}$ (both $\mathrm{P}<0.01$ ). There was no significant difference between the mice of $\mathrm{C}$ and $\mathrm{D}$ group. $(\mathrm{P}=0.154)$; the $\mathrm{VC}+$ GSH + VT Group (group E) was significantly higher in groups VC + VT Group (group C) and GSH + VT Group (group $\mathrm{D})(\mathrm{P}=0.003, \mathrm{P}=0.0047)$, but still significant lower than group $\mathrm{A}(\mathrm{P}=0.035$, Table 2$)$.

Table 2. Comparison of GSH content in stomach and duodenum of mice ( $\left.{ }^{x} \pm \mathrm{s}\right)$.

\begin{tabular}{lcc}
\hline Groups & $\begin{array}{c}\text { Stomach } \\
(\boldsymbol{\mu m o l} / \mathbf{g} \text { protein) }\end{array}$ & $\begin{array}{c}\text { Duodenum } \\
(\boldsymbol{\mu m o l} / \mathbf{g} \text { protein })\end{array}$ \\
\hline$A$ & $34.46 \pm 0.80$ & $56.00 \pm 0.18$ \\
$B$ & $27.49 \pm 0.76^{*}$ & $37.35 \pm 2.12^{*}$ \\
$C$ & $31.40 \pm 0.79^{*, \#, \Delta}$ & $48.76 \pm 1.24^{*, \#, \Delta}$ \\
$D$ & $31.87 \pm 0.35^{* \# \Delta}$ & $50.54 \pm 0.60^{*, \#, \Delta}$ \\
$E$ & $33.83 \pm 0.83^{\#}$ & $53.17 \pm 0.53^{*, \#}$ \\
\hline
\end{tabular}

The marks on right of each numeral in the table represented the statistically significant, $*$ was representative of significant at $\mathrm{P}<0.05$ level comparison with A-Group; ${ }^{\#}$ was representative of significant at $\mathrm{P}<0.05$ level comparison with $\mathrm{B}$-Group, $\mathrm{P}<0.05$; $\Delta$ was representative of significant at $\mathrm{P}<0.05$ level comparison with E-Group.

Comparison of GSH-Px activity in stomach and duodenum of mice

The GSH-Px activity in the stomach tissue was high as (51.98-63.01 units/mg protein) than in the duodenum (29.94-50.11 units/mg protein) (Table 3). The GSH-Px activity was comparatively higher in control group (group A) and VC + GSH + VT Group (group E). The lowest GSH-Px activity values of duodenum was found in mice treated with vanadyl trehalose (group B). Overall, the activity of GSH-Px in the five groups was significantly different $\quad(\mathrm{F}=9.44, \quad \mathrm{P}<0.01) \quad$ (Table 3). Compared with the control group (group A), the GSH-Px activity of mice treated with vanadyl trehalose in $\mathrm{B}$ group decreased significantly $(\mathrm{P}<0.01)$, mice having vanadyl trehalose treatment of B group has lower GSH-Px activity then mice of VC + VT Group (group C), GSH + VT Group (group D) and VC + GSH + VT Group (group E) (both $\mathrm{P}<0.01$ ). There was no significant difference between mice having treatment of vitamin $\mathrm{C}$ and vanadyl trehalose of $\mathrm{C}$ group and mice having treatment of GSH and vanadyl trehalose of $\mathrm{D}$ group $(\mathrm{P}=0.923)$. Mice of group E with VC, GSH and VT treatment was significantly higher than mice having treatment of $\mathrm{VC}+$ VT Group (group C) and GSH + VT Group (group D) $(\mathrm{P}=0.077, \mathrm{P}=0.043)$. There was no significant difference between GSH-Px activity in mice of VC + GSH + VT Group (group E) and mice of control group (group A) $(\mathrm{P}=0.77$, Table 3$)$. There was a significant difference of GSH-Px activity in the duodenum between the 5 groups $(\mathrm{F}=340.39, \quad \mathrm{P}<0.01)$. The GSH-Px activity of the duodenum in VT treated mice in group $\mathrm{B}$ was significantly lower than that mice in control group (group A) $(\mathrm{P}<0.01)$; Compared with VT Group (group B), the $\mathrm{VC}+\mathrm{VT}$ Group (group C), GSH + VT Group (group D) and mice having treatment of $\mathrm{VC}+\mathrm{GSH}+\mathrm{VT}$ (group E) were significantly improved (both $\mathrm{P}<0.01$ ), and group $\mathrm{VC}+\mathrm{GSH}+\mathrm{VT}$ Group (group E) was significantly higher than $\mathrm{VC}+\mathrm{VT}$ Group (group C) and GSH + VT Group (group D) $(\mathrm{P}=0.003, \mathrm{P}=0.018)$, but the difference between groups VC + VT Group (group C) and GSH + VT Group (group D) was not statistically significant $(\mathrm{P}=0.325)$; Mice having treatment of vanadyl trehalose (group B) was still lower than control group (group A), and the difference was statistically significant $(\mathrm{P}=0.008$, Table 3).

Table 3. Comparison of GSH-Px activity in stomach and duodenum of mice $\left({ }^{x} \pm s\right)$.

\begin{tabular}{lcc}
\hline Groups & $\begin{array}{c}\text { Stomach } \\
\text { (units/mg protein) }\end{array}$ & $\begin{array}{c}\text { Duodenum } \\
\text { (units/mg protein) }\end{array}$ \\
\hline$A$ & $63.01 \pm 2.12$ & $50.11 \pm 0.20$ \\
$B$ & $51.98 \pm 2.30^{*}$ & $29.94 \pm 0.74^{*}$ \\
$C$ & $57.43 \pm 2.75^{*, \#, \Delta}$ & $45.67 \pm 1.04^{*, \#, \Delta}$ \\
$D$ & $57.63 \pm 0.70^{*, \#, \Delta}$ & $46.31 \pm 0.39^{*, \#, \Delta}$ \\
$E$ & $62.39 \pm 1.83^{\#}$ & $48.05 \pm 0.29^{*, \#}$ \\
\hline
\end{tabular}

The marks on right of each numeral in the table represented the statistically significant, $*$ was representative of significant at $\mathrm{P}<0.05$ level comparison with A-Group; \# was representative of significant at $\mathrm{P}<0.05$ level comparison with $\mathrm{B}$-Group, $\mathrm{P}<0.05$; ${ }^{\Delta}$ was representative of significant at $\mathrm{P}<0.05$ level comparison with E-Group. 
Changes of $m R N A$ expression of GSH/GSTs pathwayrelated genes in stomach of mice

After 15 days of continuous treatment, the expression of each gene in the gastric tissue of the 5 groups was statistically significant (GCLC: $\mathrm{F}=32.94$, $\mathrm{P}<0.01 ;$ GSS: $\mathrm{F}=22.73, \mathrm{P}<0.01 ;$ GSR: $\mathrm{F}=20.22, \mathrm{P}<0.01$; pi-glutathione S-transferase (GSTpi): $\mathrm{F}=27.39, \mathrm{P}<0.01)$; The expressions of GCLC, GSS, GSR and GSTpi in gastric tissue of VT Group (group B) mice were significantly lower than those in mice of control group (group A) (both $\mathrm{P}<0.01$ ). The expressions of GCLC, GSS and $G S R$ in VC + VT Group (group C), GSH + VT Group (group D) and VC + GSH + VT Group (group E) were significantly higher than those mice treated with vanadyl trehalose in group $\mathrm{B}$ (both $\mathrm{P}<0.05$ ). The expression of GCLC, GSS and GSR in mice group $\mathrm{E}$ having treatment of vitamin $\mathrm{C}, \mathrm{GSH}$ and vanadyl trehalose was significantly higher than mice in $\mathrm{VC}+\mathrm{VT}$ Group (group C) and GSH + VT Group (group D) (both $\mathrm{P}<0.05$ ), but no significant difference with control group (group A), and the difference between VT Group (group C) and GSH + VT Group (group D) is not obvious (both $\mathrm{P}>0.05$ ); the expression of GSTpi has no statistically significant difference among VC + VT Group (group C), $\mathrm{GSH}+\mathrm{VT}$ Group (group D) and group $\mathrm{E}(\mathrm{P}>0.05$, Fig. 1).
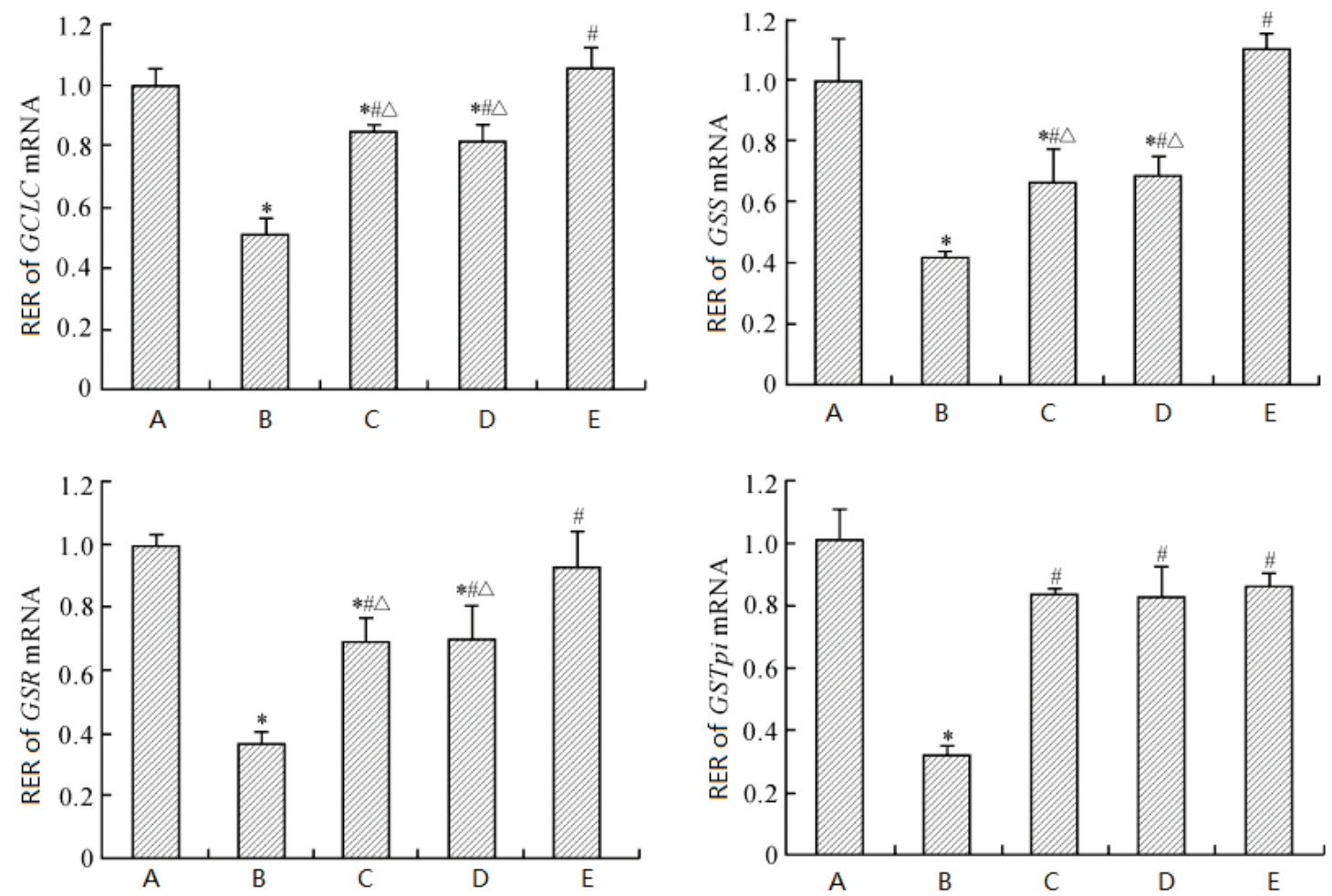

Fig. 1. The mRNA Relative expression rate (RER) of reduced glutathione/ glutathione-S-transferase GSH/GSTs pathway related genes in mice stomach tissue. The RER value of ordinate was the ratio compared with control group $A$; The abscissa was represented the mince groups A, B, C, D and E; The marks on each column represented the statistically significant, * was representative of significant at $\mathrm{P}<0.05$ level comparison with A-Group; ${ }^{*}$ was representative of significant at $\mathrm{P}<0.05$ level comparison with $\mathrm{B}-\mathrm{Group}, \mathrm{P}<0.05 ;{ }^{\Delta}$ was representative of significant at $\mathrm{P}<0.05$ level comparison with $\mathrm{E}-\mathrm{Group}$.

Changes of $m R N A$ expression of GSH/GSTs pathwayrelated genes in duodenum of mice

The expression of each gene in the duodenum of the 5 groups was statistically significant (GCLC: $\mathrm{F}=126.74, \quad \mathrm{P}<0.01 ; \quad$ GSS: $\mathrm{F}=21.86, \quad \mathrm{P}<0.01 ; \quad G S R$ : $\mathrm{F}=26.41, \mathrm{P}<0.01 ;$ GSTpi: $\mathrm{F}=41.05, \mathrm{P}<0.01)$. Compared with control group (group A), the GCLC, GSS, GSR and GSTpi expression in the mice duodenum of VT Group (group B) were all significantly down-regulated (both
$\mathrm{P}<0.01$ ), and the mice in $\mathrm{VC}+\mathrm{VT}$ Group (group $\mathrm{C}$ ), $\mathrm{GSH}+\mathrm{VT}$ Group (group D) and VC + GSH + VT Group (group E) were significantly higher than those of the mice having vanadyl trehalose treatment (group B) (both $\mathrm{P}<0.05)$. Compared with the $\mathrm{VC}+\mathrm{GSH}+\mathrm{VT}$ Group (group E) was significantly increased (both $\mathrm{P}<0.05$ ), but only GSR expression returned to the control group (group A) $\quad(\mathrm{P}=0.954)$. There were no significant differences in the expressions of GCLC, GSS and GSTpi 
between mice of VC + VT Group (group C) and GSH + VT Group (group D) (all P $>0.05$ ), but the expression of GSR in mice with vitamin $\mathrm{C}$ and vanadyl trehalose treatment Group (group C) was significantly higher than that in GSH + VT Group (group D) $(\mathrm{P}=0.035)$; there was no significant difference in GSTpi expression among the VC + VT Group (group C), GSH + VT Group (group D) and $\mathrm{VC}+\mathrm{GSH}+\mathrm{VT}$ Group (group E) are all significantly lower than the control group (group A) (all $\mathrm{P}<0.05$, Fig. 2).
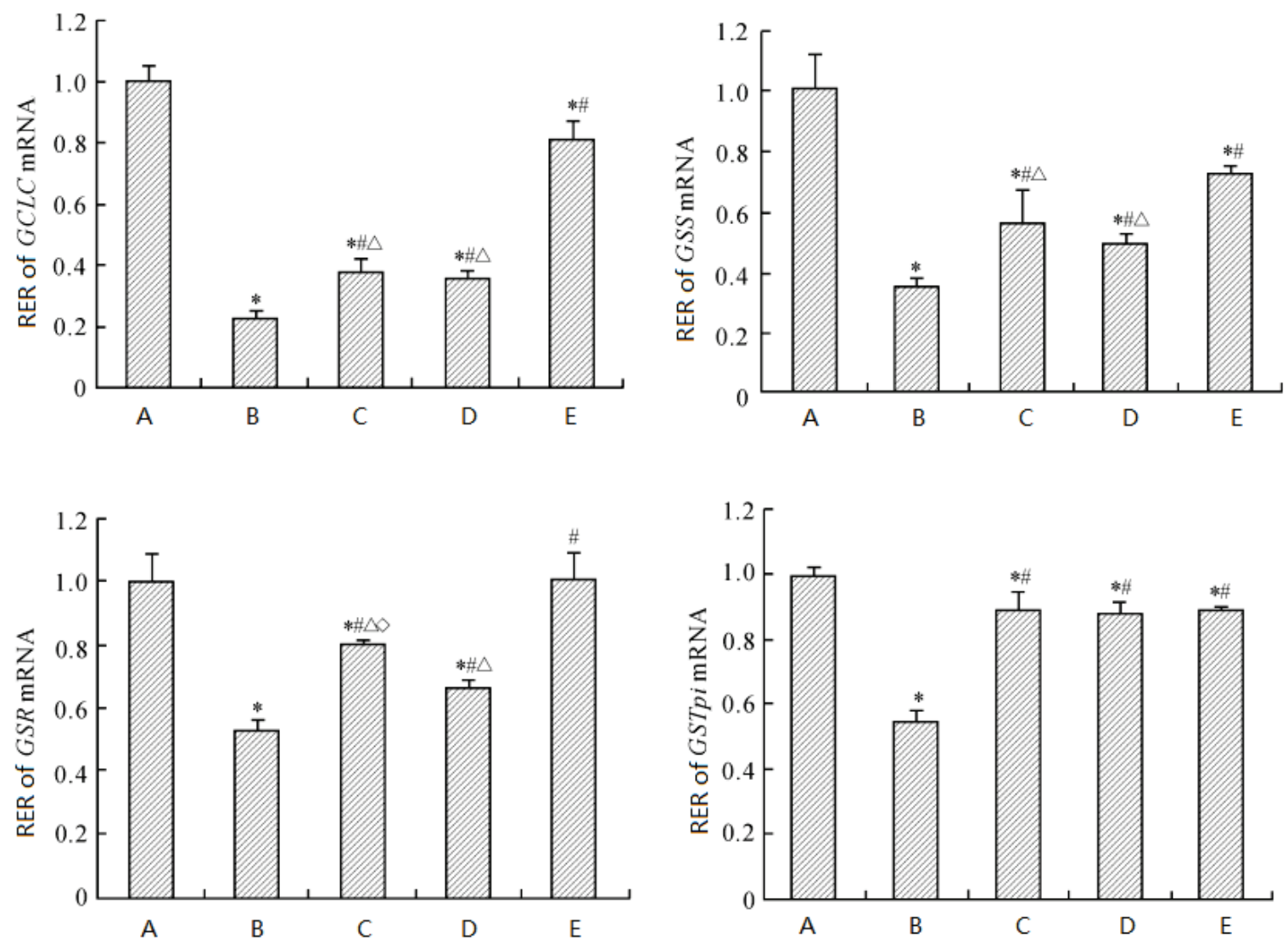

Fig. 2. The mRNA Relative expression rate (RER) of reduced glutathione/ glutathione-S-transferase (GSH/GSTs) pathway related genes in mice duodenum tissue. The RER value of ordinate was the ratio compared with control group $A$; The abscissa was represented the mince groups A, B, C, D and E; The marks on each column represented the statistically significant, * was representative of significant at $\mathrm{P}<0.05$ level comparison with A-Group; ${ }^{\#}$ was representative of significant at $\mathrm{P}<0.05$ level comparison with $\mathrm{B}-\mathrm{Group}, \mathrm{P}<0.05 ;{ }^{\Delta}$ was representative of significant at $\mathrm{P}<0.05$ level comparison with $\mathrm{E}-\mathrm{Group}$.

\section{Discussion}

Oxidative stress refers to the body suffering a variety of harmful stimuli, the highly active molecules such as reactive oxygen species (ROS) excessive production, the body cannot be removed in time, oxidation system and antioxidant system imbalance, resulting in tissue damage (Gyuraszova et al. 2018, Trebaticky et al. 2019). ROS include superoxide anion $\left(\mathrm{O}_{2}-\right)$, hydroxyl radical $(\mathrm{OH})$ and hydrogen peroxide $\left(\mathrm{H}_{2} \mathrm{O}_{2}\right)$ (Wiecek et al. 2015, Linhartova et al. 2016). Under physiological conditions, vanadium exists mainly in the form of +5 and +4 valence states, and the form transition frequently accompanied the ROS production.
$\mathrm{V}^{4+}$ generates $\mathrm{V}^{5+}$ through the Fenton reaction and produces a large amount of $\mathrm{OH}$. After the vanadium compound stimulates the cells, the intracellular P47phox protein is phosphorylated, thereby activating NADPH oxidase and producing a large amount of $\mathrm{O}_{2}$ - in the cells (Lushchak 2014). There are two types of antioxidant systems in the body: one is the enzyme antioxidant system, including superoxide dismutase (SOD), catalase (CAT), glutathione peroxidase (GSH-Px), etc.; and the other is non-enzymatic antioxidant system, including vitamin $\mathrm{C}$, vitamin $\mathrm{E}$, GSH, carotenoids and selenium (Se) (Patrik et al. 2017).

In this study, after 15 days of continuous intragastric administration, the results showed that the 
GSH content and GSH-Px activity in the stomach and duodenum of the VT group were lower than those of the control group. The main reasons may be: 1) GSH is oxidized and consumed during the conversion of pentavalent vanadium to tetravalent vanadium; 2) vanadium and GSH have high affinity, which leads to direct binding; 3 ) the GSH oxidized by vanadium induced ROS leads a decrease in the level of GSH in the body cells. Lack of or depletion of GSH in the body can aggravate the toxic effects of various chemicals and increase oxidative damage (Nemeti et al. 2002). Mice fed with VT reduced the activity of glutathione peroxidase (GSH-Px), probably because its vanadium ion has a strong affinity with $-\mathrm{SH}$, and the binding of $-\mathrm{SH}$ to the active center of GSH-Px leads to a decrease in viability. In addition, it may be related to the fact that vanadium is easily combined with the GSH-Px substrate GSH to reduce the GSH-Px activity.

Infusion of VT impairs the gastrointestinal antioxidant system of mice and causes oxidative stress in the body. Folarin et al. (2017) found that vanadium caused a decrease in GSH content and GSH-Px activity in mouse brain. It has also been reported in the literature that vanadium can reduce the GSH content of rat hepatocytes (Hosseini et al. 2013). The results of this study showed that exogenous supplementation of VC and GSH can increase the GSH content and GSH-Px activity in the stomach and duodenum of mice, but only when the two are used together, the GSH content and GSH-Px activity in the stomach can be restored to the control level, indicating that the effect of VT on duodenal GSH content and GSH-Px activity was more evident than that of gastric tissue. Exogenous GSH supplementation can directly increase the GSH content in the body, help to scavenge free radicals, and produce cross-linking complexes with electrophilic complexes under the action of non-enzymatic or glutathione thiol transferase (GST) to form sulfur etherase excreted in vitro, increasing cell detoxification function, accelerating the excretion rate of toxic by-products, and reducing the toxicity of vanadium. Wang et al. (2015) reported that exogenous GSH can accelerate the excretion of arsenic in mice and reduce the oxidative stress induced by arsenic, thus reducing the toxicity of arsenic. Exogenous supplementation of VC can increase collagen synthesis and repair, protect mucosal cells, maintain the integrity of the structure and function of the gastrointestinal tract, and rapidly react with $\mathrm{O}_{2-}, \mathrm{H}_{2} \mathrm{O}_{2}$ and $\mathrm{OH}$ to form semi-dehydroascorbic acid to eliminate or reduce these free radicals thus prevent or reduce oxidative damage in the cells. It has also been reported that $\mathrm{VC}$ can increase the antioxidant capacity of intestinal epithelial cells and reduce their oxidative damage (Liu et al. 2012).

GSH/GSTs are essential antioxidant and detoxification systems for animals. GSH synthesis (GCLC, GSS, GSR) and catabolism-related enzyme genes (GSTpis) constitute an intact GSH/GSTs functional system and a relatively complete pathway (Kalinina et al. 2014). In vivo, reduced GSH is synthesized by $\gamma$-GCL and GSS with an amino acid as substrate. Among them, $\gamma$-GCL is a restriction enzyme, GCLC is the catalytic subunit of the enzyme; meanwhile, it can also be under the action of GSR and NADPH reduction of oxidized glutathione (GSSG) to GSH ( $\mathrm{Lu} 2013$ ). The results of this study showed that the expression of GCLC, GSS and GSR genes in the stomach and duodenum were down-regulated in the VT-administered group compared with the control group, indicating that VT has certain toxicity to the stomach and duodenum that caused dysfunction, which interferes with the normal expression of related genes. Exogenous supplementation of $\mathrm{VC}$ and GSH and their combination can increase the mRNA expression of $G C L C$, GSS and GSR genes, and only the expression of gastric tissue in the combination group can be restored to the control level, which is related to the GSH content. The effects of GSH-Px activity are consistent. It is speculated that exogenous addition of VC and GSH may increase the antioxidant capacity in the body, protect the function of the stomach and duodenum and reduce the influence of VT side effects on the expression of related genes. It is worth noting that the expression of GSR in the duodenum in supplemental VC group was significantly higher than that in the supplemental GSH group, and the combination of the two could restore the expression to the control level. It may be that $\mathrm{VC}$ is more effective than GSH to increases GSR activity and the amount of GSH in the body, therefor the combination supplementation of $\mathrm{VC}$ and GSH restore cellular function to normal levels (Liu et al. 2012).

Glutathione S-transferases (GSTs) belong to the isoenzyme family of phase II metabolic detoxification enzymes and have the dual functions of scavenging free radicals and detoxification in vivo. GSTpi is an important member of the GSTs family, it can participate in the metabolism of a variety of internal and exogenous substances, remove harmful substances, reduce the body's oxidative damage and protect cells (Schnekenburger et al. 2014). The results in this study showed that VT was toxic 
to the stomach and duodenum, impairing the normal function of the cells, resulting in a decrease in GSTpi expression. Exogenous supplementation of VC and GSH and their combination increased GSTpi expression, only in the stomach tissue was comparable to the control group, indicating that VT had more significant effect on the duodenum.

The dose of VT used in the study was comparable to doses in which VT effectively reduces blood glucose levels previous research reported by Barrio et al. (2003) and Jiang et al. (2016). The results in this study also showed that although separately supplementation of VC and GSH had improved effects on each index than the VT-administered group, but they did not reach the control level. There may be limitations in the use of $\mathrm{VC}$ and $\mathrm{GSH}$ alone or may be related to insufficient supplementation. When $\mathrm{VC}$ and $\mathrm{GSH}$ are combined supplementation, which results some indicators return to normal levels, and the effect is better than $\mathrm{VC}$ and GSH alone, indicating that $\mathrm{VC}$ and $\mathrm{GSH}$ have a synergistic effect in addition to their own antioxidant effects. VC and GSH form a coupled redox couple in vivo, when $\mathrm{VC}$ is oxidized to dehydrogenated $\mathrm{VC}$, the activity of GSH-dependent dehydrogenase $\mathrm{VC}$ reductase plays an important role in maintaining the $\mathrm{VC}$ physiological cycle, and VC can also reduce the oxidized glutathione (GSSH) to GSH, which increases its content and assist it to function (Gao et al. 2002).

\section{Conclusions}

Vanadyl trehalose was able to cause oxidative stress damage to the gastrointestinal tract of mice, which affects GSH content and GSH-Px activity, and interferes with the regular expression of GSH/GSTs pathway related. Exogenous vitamin $\mathrm{C}$, reduced glutathione and the combination of the two could play a certain role in antioxidant protection and reduce the toxicity of vanadyl trehalose. The combination of the two is better than the use alone, and the relevant indicators in the stomach can reach the normal level.

\section{Conflict of Interest}

There is no conflict of interest.

\section{Acknowledgements}

This work is supported by the National Natural Science Foundation of China (31771066) and the Key Technologies R\&D Program of Tianjin (18YFZCSY00030 and 18YFZCNC01200).

\section{References}

BARRIO DA, WILLIAMS PA, CORTIZO AM: Synthesis of a new vanadyl (IV) complex with trehalose (Trevo): insulin-mimetic activities in osteoblast-like cells in culture. J Bio Inorg Chem 8: 459-468, 2003. https://doi.org/10.1007/s00775-002-0438-z

CANIVELL S, GOMIS R: Diagnosis and classification of autoimmune diabetes mellitus. Autoimmun Rev 13: 403-407, 2012. https://doi.org/10.1016/j.autrev.2014.01.020

FOLARIN OR, ADARAMOYE OA, AKANNI OO: Changes in the brain antioxidant profile after chronic vanadium administration in mice. Metab Brain Dis 6: 1-9, 2017. https://doi.org/10.1007/s11011-017-0070-9

GYURASZOVA M, KOVALCIKOVA A, JANSAKOVA K, SEBEKOVA K, CELEC P, TÓTHOVA L: Markers of oxidative stress and antioxidant status in the plasma, urine and saliva of healthy mice. Physiol Res 67: 921-934, 2018. https://doi.org/10.33549/physiolres.933866

GAO F, YAO CL, GAO E: Enhancement of glutathione cardioprotection by ascorbic acid in myocardial reperfusion injury. J Pharmacol Exp Ther 301: 543-550, 2002. https://doi.org/10.1124/jpet.301.2.543

GAVIN JR, ALBERTI K, DAVIDSON MB: Report of the expert committee on the diagnosis and classification of diabetes mellitus. Diabetes Care 20: 1183-1197, 1997. https://doi.org/10.2337/diacare.20.7.1183

HOSSEINI MJ, SHAKI F, GHAZI KM: Toxicity of vanadium on isolated rat liver mitochondria: A new mechanistic approach. Metallomics 5: 152-166, 2013. https://doi.org/10.1039/c2mt20198d

IMURA H, SHIMADA A, NAOTA M: Vanadium toxicity in mice: possible impairment of lipid metabolism and mucosal epithelial cell necrosis in the small. Toxicol Pathol 41: 842-856, 2013. https://doi.org/10.1177/0192623312467101 
JIANG PZ, DONG Z, MA BC: Effect of vanadyl rosiglitazone, a new insulin-mimetic vanadium complexes, on glucose homeostasis of diabetic mice. Appl Biochem Biotech 180: 841-851, 2016. https://doi.org/10.1007/s12010-0162137-1

JIANG PZ, NI ZZ, WANG B: Acute toxicity, twenty-eight days repeated dose toxicity and genotoxicity of vanadyl trehalose in Kunming mice. Regul Toxicol Pharm 85: 86-97, 2017. https://doi.org/10.1016/j.yrtph.2017.02.001

JIANG PZ, LIU QQ, NI ZZ: Primary study on the toxic mechanism of vanadyl trehalose in Kunming mice. Regul Toxicol Pharm 94: 1-7, 2018. https://doi.org/10.1016/j.yrtph.2017.12.025

KALININA EV, CHERNOV NN, NOVICHKOVA MD: Role of glutathione, glutathone transferase, processes glutaredoxin in regulation of redox-dependent. Biochem 79: 1562-1583, 2014. https://doi.org/10.1134/s0006297914130082

LEE JC, SON YO, PRATHEESHKUMAR P: Oxidative stress and metal carcinogenesis. Free Radic Biol Med 53: 742-757, 2012. https://doi.org/10.1016/j.freeradbiomed.2012.06.002

LINHARTOVA P, GAZO I, SAMPELS S: Combined incubation of cadmium, docosahexaenoic and eicosapentaenoic acid affecting the oxidative stress and antioxidant response in human hepatocytes in vitro. Physiol Res 65 : 609-616, 2016. https://doi.org/10.33549/physiolres.933247

LIU C, CHI L, LIN F: Study on the protective effect of vitamin C on intestinal epithelial cells oxidative damage in Jian carp. Acta Zoonutr Sin 24: 1503-1511, 2012.

LU SC: Glutathione synthesis. Biochim Biophys Acta 1830: 3143-3153, 2013. https://doi.org/10.1016/j.bbagen.2012.09.008

LUSHCHAK VI: Free radicals, reactive oxygen species, oxidative stress and its classification. Chem Biol Interact 224 : 164-175, 2014. https://doi.org/10.1016/j.cbi.2014.10.016

MONACELLI F, ACQUARONE E, GIANNOTTI C, BORGHI R, NENCIONI A: Vitamin C, aging and Alzheimer's disease. Nutrients 9: 670, 2017. https://doi.org/10.3390/nu9070670

NEMETI B, ANDERSON ME, GREGUS Z: Glutathionesynthetase promotes the reduction of arsenate via arsenolysis of glutathione. Biochimie 94: 1327-1333, 2002. https://doi.org/10.1016/j.biochi.2012.02.033

PATRIK P, KLAUDIA J, MIRIAMA S: Targeting free radicals in oxidative stress-related human diseases. Trends Pharmacol Sci 7: 592-607, 2017. https://doi.org/10.1016/j.tips.2017.04.005

RADOSINSKA J, KURAHARA LH, HIRAISHI K, VICZENCZOVA C, EGAN BENOVA T, SZEIFFOVA BACOVA B, DOSENKO V, NAVAROVA J, OBSITNIK B, IMANAGA I, SOUKUP T, TRIBULOVA N: Modulation of cardiac connexin-43 by omega-3 fatty acid ethyl-ester supplementation demonstrated in spontaneously diabetic rats. Physiol Res 64: 795-806, 2015. https://doi.org/10.33549/physiolres.933413

RAHMAN I, KODE A, BISWAS SK: Assay for quantitative determination of glutathione and glutathione disulfide levels using enzymatic recycling method. Nat Protoc 6: 3159, 2006. https://doi.org/10.1038/nprot.2006.378

SCHNEKENBURGER M, KARIUS T, DIEDERICH M: Regulation of epigenetic traits of the glutathione S-transferase P1 gene: from detoxification toward cancer prevention and diagnosis. Front Pharmacol 5: 1-7, 2014. https://doi.org/10.3389/fphar.2014.00170

SU M, CHEN H, WEI C, CHEN N, WU W: Potential protection of vitamin C against liver-lesioned mice. Int Immunopharmacol 22: 492-497, 2014. https://doi.org/10.1016/j.intimp.2014.07.034

TREBATICKY B, ZITNANOVA I, DVORAKOVA M, ORSZAGHOVA Z, PADUCHOVA Z, DURACKOVA Z, BREZA J, MUCHOVA J: Role of oxidative stress, adiponectin and endoglin in the pathophysiologof erectile dysfunction in diabetic and non-diabetic men. Physiol Res 68: 623-631, 2019. https://doi.org/10.33549/physiolres.934129

WANG J, YUEN VG, MCNEILL JH: Effect of vanadium on insulin sensitivity and appetite. Metabolism 50: 667-673, 2001. https://doi.org/10.1053/meta.2001.23294

WIECEK M, MACIEJCZYK M, SZYMURA J, SZYGULA Z: Changes in oxidative stress and acid-base balance in men and women following maximal-intensity physical exercise. Physiol Res 64: 93-102, 2015. https://doi.org/10.33549/physiolres.932744

WANG D, LIN L, LI X, SUN GF: Effects of glutathione on the vivo metabolism and oxidative stress of arsenic in mice. J Toxicol Sci 40: 577-583, 2015. https://doi.org/10.2131/jts.40.577 
WHITING DR, GUARIGUATA L, WEIL C: IDF Diabetes Atlas: Global estimates of the prevalence of diabetes for and 2030. Diabetes Res Clin Pract 94: 311-321, 2013. https://doi.org/10.1016/j.diabres.2011.10.029

WILK A, SZYPULSKA-KOZIARSKA D, WISZNIEWSKA B: The toxicity of vanadium on gastrointestinal, urinary and reproductive system, and its influence on fertility and fetuses malformations. Postepy Hig Med Dosw (Online) 71: 850-859, 2017. https://doi.org/10.5604/01.3001.0010.4783

XIAODAN LI, TU P, UMAR M, LIU Q, LUO W, YANG X, ZHU J, KONG D, LI M: A study on molecular mechanisms of adiposis induced by long-term treatment of high-fat and high-sucrose in C57BL/6J mice. Physiol Res 68: 75-87, 2019. https://doi.org/10.33549/physiolres.933830

ZHAO X, SONG JL, YI R, LI G, SUN P, PARK KY, SUO H: Comparison of antioxidative effects of Insect tea and its raw tea (Kuding tea) polyphenols in Kunming mice. Molecules 23: 204, 2018. https://doi.org/10.3390/molecules23010204 